\title{
European Competition Law Review
}

2015

The Brussels Court judgement in Commission v Elevators manufacturers, or the story of how the Commission lost an action for damages based on its own infringement decision

\author{
Jorge Marcos Ramos*
}

Daniel Muheme**

\section{Subject: Competition law. Other related subjects: Damages}

Keywords: Belgium; Cartels; Causation; Collusive tendering; Damages; EU law; European Commission; Private enforcement

Legislation: Treaty on the Functioning of the European Union art.101

Civil Code (Belgium) art.1349, art.1382

Directive 2014/104 on actions for damages under national law for infringements of the competition law provisions [2014] O] L349/1

Cases: European Commission v Producers of Elevators unreported 24 November 2014 (RvK (Brussels))

\section{European Commission v Otis NV (C-199/11)_[2013] 4 C.M.L.R. 4 (EC] (Grand Chamber)).}

\section{${ }^{*} E . C . L . R .384$ 1. Introduction}

On November 24, 2014, the Brussels Court of Commerce (the Brussels Court) dismissed the European Commission's (Commission) own claim for antitrust damages in respect of the harm inflicted by the elevators and escalators cartels. $\frac{1}{}$ Readers will recall that in 2007 , the Commission had slapped a close to $€ 1$ billion fine on four manufacturers of lifts and elevators who had unlawfully colluded in public tenders launched by the EU institutions. $\underline{2}$

The timing of the Brussels Court judgment is particularly interesting. It comes only weeks after the Commission passed a successful legislative Directive on antitrust damages that purports to promote private enforcement. With this judgment, some may find evidence that this bill was well needed. Others will in contrast read in the judgment a confirmation that antitrust damages litigation is a doomed enterprise, and that the Directive is unlikely to ever improve this.

With this background, this article offers a comprehensive review of the Brussels Court judgment. The structure of the paper is as follows. (1) Part I gives a concise overview of the facts; (2) Part II summarises and discusses the assessment of the Brussels Court with a particular focus on evidence analysis; (3) Part III provides a more economic perspective on incomplete bid-rigging cartels; (4) and concludes (5). 


\section{Facts}

In 2007 the Commission found that the elevators manufacturers KONE, Otis, Schindler and ThyssenKrupp (KOST), 3 had committed an infringement of art.101 TFEU from 1996 to 2004 in Belgium, Germany, Luxembourg and the Netherlands. The companies had agreed to: (i) allocate public tenders between themselves and other contracts for the sale, installation and servicing of elevators and escalators; (ii) not to compete with each other; and (iii) had exchanged commercially sensitive information. The Commission fined the four elevators manufacturers a total amount of $€ 992$ million. This fine constituted a record-high fine at that time.

Shortly thereafter, the Commission filed a claim for damages before the Brussels Court against the cartel participants. The action for damages was lodged on behalf of the European Institutions. They had presumably suffered additional costs in several calls for tenders in relation to elevators and escalators. Interestingly, the Commission claimed that its own calls for tenders had been affected by the artificial market allocation: the Commission had concluded agreements with several of the undertakings for the maintenance and the modernisation of its elevators during the infringement period.

In support of its action, the Commission sought the expert assistance of an economic consultancy firm, which was tasked with estimating the damages presumably inflicted by the cartel on the European Institutions. The report of the economic consultancy (the MAPP report) concluded that: (i) the characteristics of the affected markets by the cartel suggested that it had a considerable influence on the price paid by the Commission; and (ii) measured the damages that the cartel had caused to the European Institutions on the basis of a statistical analysis of some of the maintenance contracts from 1997 until 2003.

On the basis of the MAPP report, the Commission sought to obtain the nullity of the contracts entered into with KOST based on fraud, $\underline{4}$ as well as damages in the ballpark of $€ 6$ million. According to the Commission, the*E.C.L.R. 385 damages corresponded to the cartel price mark-up paid by the European Institutions for the maintenance contracts of its different buildings, both in Brussels and Luxembourg.

KOST contested both the existence and the amount of the claimed damages, as well as the causal link between the infringement and the damages.

\section{Assessment by the national court}

\section{(i) Interim judgment of the Brussels Court and preliminary references before the CJEU}

Readers will recall that the proceedings did not start very smoothly. In the early days of the procedure, KOST disputed the Commission's standing in the proceedings in its capacity to act as the representative of the European Institutions. Further, KOST claimed that the Commission did not have an express authorisation from the other European Institutions that 
had suffered harm as a result of the infringement. The cartelists also contended that the Commission was infringing the principles of judicial independence and equality of arms.

Those early allegations led the Brussels Court to stay proceedings, issue an interim judgment $\frac{5}{}$ and refer two preliminary questions to the CJEU concerning the authority of the Commission to represent the European Institutions, and the right to a fair trial. $\underline{6}$

In response to the Brussels Court, the CJEU first recalled that it was clear from the wording of art.282 EC that if the EU was to be a party to legal proceedings before a national court then it ought to be represented by the Commission. $\underline{?}$

Secondly, the CJEU maintained that the effective enforcement of competition law requires that any party can seek damages caused by any infringement of competition law provisions, in line with its Manfredi case law. $\underline{8}$ Consequently, the right to a fair trial, as guaranteed by art.47 of the Charter of Fundamental rights and art. 6 of the European Treaty on Human Rights is not infringed when the Commission introduces an action for damages to redress an infringement that has been established by its own decision.

The CJEU recalled the Manfredi case law that provides the framework for such actions. Damages will only be awarded when the three following elements are present: (i) a harmful event (i.e. the concerted practice); (ii) the existence of damages; and (iii) a direct causal link. The infringement of art.101 TFEU as established in the Commission's Decision allowed the Belgian judge to limit its assessment to the existence of damages and the causality link. $\underline{9}$

That said, the fact that the Commission has established the existence of a harmful event in its decision and that the national judge is bound by it does not prevent the national judge from judging independently on the existence and the quantum of these damages and the causal link. Indeed, whether a national judge can review the infringement decision is only a matter of distribution of competences between the national judge and the European Union judge. This distribution of competences consequently does not lead to the conclusion that the Commission is judge and party in its own case.

Ultimately, the CJEU recognised that the Commission was not infringing the principle of equality of arms. The Commission had not used any information obtained during the investigation conducted against KOST for the infringement decision to sustain its damages claim.

\section{(ii) Legal qualification of the claim under Belgian law based on article 1382 of the Belgian Civil Code (CC)}

Let us now revert to the Brussels Court's judgment. For a start, the Brussels Court recalls that to establish personal liability a claimant must, under Belgian tort law, demonstrate that three conditions are met: (a) a harmful event; (b) damages (loss suffered) and a causal link 
between both. If a claimant cannot prove the existence of those three cumulative conditions, it cannot be awarded any damages and as a consequence (c) "the loss rests were it falls". $\underline{10}$

\section{(a) Harmful event}

The first liability condition is swiftly dealt with. As explained above, the Brussels Court is bound by the Commission's Decision. $\frac{11}{1}$ The anti-competitive nature of the agreements between the cartelists on the Belgian market thus qualifies as a harmful event, which automatically gives rise to civil liability when the harm is caused.

\section{(b) Damages and causal link}

By virtue of the EU general principle of procedural autonomy, national law governs the assessment of damages and of the causal link. The Brussels Court*E.C.L.R. 386 however reminds that its analysis needs to comply with the principles of equality and effectiveness, as stated in Manfredi.

On damages, the Belgian CC provides no definition. This notion has been developed in the case law and doctrine. The Belgian Court of Cassation defined damages as any loss or right impairment that belongs to anyone's patrimony or the loss of an advantage that could have

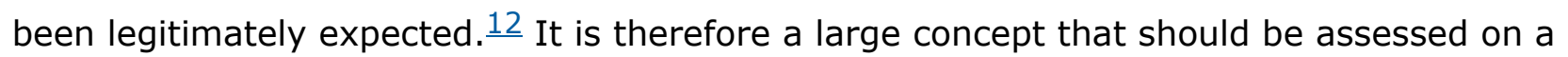
case-by-case basis. Under Belgian law there is a difference between "the certainty on the existence of damages" and "the certainty on its quantum". This seeks to ensure that lack of certainty (or indeterminacy) of the quantum does not prevent the victim from compensation. Both the existence of the damage, as well as its quantum, are assessed in a discretionary way by the Belgian judge.

The objective of a damages claim is to replace the injured parties as much as possible into the position where they would have been had the harmful event not occurred. The compensation of the injured parties is therefore the main objective of the claim for damages.

On causation, the claimant should demonstrate the damages suffered and should not simply make it hypothetically. Therefore, under Belgian law, $\underline{13}$ the main question for the assessment of the alleged damages caused by the cartel entails a counterfactual analysis: what would have happened had the infringement never occurred. Hence, on the basis of an estimate, a reference scenario should be established with which the factual situation can be compared. This scenario is called the "non-infringement scenario" or the "counterfactual scenario". 14 The Brussels Court takes into account the specificities of the case and the proof that it disposes of, in order to examine whether the claimant truly suffered damages that are imputable to the infringement and if so, to determine their extent.

In this case, the Brussels Court did not dispose of direct evidence that could be relevant to determine or estimate the damages. Even if oral evidence of witnesses could be used, the 
Commission did not provide for any of these.

\section{(c) Evidence analysis of the Brussels Court on damages and causation}

When the Commission lodged its action for damages before the Brussels Court in 2008, the Antitrust Damages Directive ${ }^{15}$ was not yet applicable. The Brussels Court therefore excluded the application of the Directive's rebuttable presumption, although it embraced the idea that a cartel generally causes damages.

In this regard, and as a general matter of law, the Brussels Court held that the economic variables that can be considered depend on the kind of damages claimed by the applicant. The Brussels Court finds it acceptable to consider that in general cartels raise prices, but it argues that prices are rarely determined by one factor.

To assess a price increase or overcharge, a non-infringing price is used as the reference for a comparison with the actual prices paid by consumers. Nevertheless, the Brussels Court considers that it is impossible to determine with certainty how the market would have evolved absent an infringement of art.101 TFEU. Prices, sales volumes and profit margins depend on several complex factors where the strategic interactions between participants of the market play a fundamental role. Moreover, these factors are difficult to assess. The hypothetical non-infringement scenario therefore relies on different uncertain assumptions.

In casu, the Brussels Court emphasised that: (i) the cartel consisted of a market allocation for tender procedures, i.e. a bid-rigging and an "atypical" price-fixing practice; (ii) that the damages claimed should eventually amount to the overcharge paid by the EU Institutions; and (iii) that the alleged damages only related to the maintenance of existing elevators and escalators.

With these elements in hand, the Brussels Court then proceeded to the analysis and rejection of all the evidence provided by the Commission. In particular, the Brussels Court makes the decision of the Commission its own, and dismisses the normal course of (market) practices and the economic reports advocating damages or a loss of opportunity.

\section{The Elevators decision of the Commission and the MAPP report}

Under Belgian law, the "normal market practices" standard is well-known in the sense of art.1349 CC. In short, if an action generally causes damages the causal link can be proven invoking that under the normal course of market practices this action generally causes damages. A contrario, the burden of proof is reversed if the defendant invokes a fact contrary to the normal market practices.

The principle entails that contracts concluded during the period of the cartel are necessarily influenced by the cartel. And these contracts should lead to higher prices than contracts concluded in a free market without distortions of competition. This is nothing but a basic 
economic assumption: the cartel allocating markets implies, de facto, a decrease in the number of players on the supply side, thereby increasing prices on the demand side. *E.C.L.R. 387

The Brussels Court further explains that agreements on the allocation of public and private tenders might indeed have an impact on the price stemming from the "cartelized contracts". Nevertheless, the Brussels Court highlights that one of the studies presented by the Commission states that in the case of a bid-rigging cartel an effect on price cannot simply be accepted when 30 per cent of competitors do not participate in the cartel. Referring to a study from the competition consultancy agent OXERA, which was prepared for the Commission in 2009, $\underline{16}$ the Brussels Court embraces the idea that in case of public tenders with competitors falling outside of the cartel, this might have no influence on the price. Contrary to what the Commission claimed, it does not belong to the normal course of (market) practices that bid-rigging cartels leads to higher prices.

In support of the view that the bid-rigging practices at issue did not influence prices, the Brussels Court stresses the inaccuracy of the Commission's contentions $\frac{17}{17}$ and recalls that the cartel consisted of 70 per cent of the market players, so that the other 30 per cent of the players could also compete for the maintenance contracts. The Commission was therefore wrong to allege that the four undertakings had a quasi-monopoly position and could hence charge any price. KOST had to take into account the possible competition with the undertakings that were not part to the cartel.

The Court even quotes the Commission's decision to stress the difficulty of establishing the precise effects of an infringement when the cartel does not cover the entire industry:

"In this case, the Commission did not attempt to demonstrate the precise effects of the infringement since it is impossible to determine with sufficient certainty the relevant competitive parameters (price, commercial terms, quality, innovation, and others) in the absence of the infringements. However it is obvious that the infringements did have an actual impact. The fact that the various anticompetitive arrangements were implemented by the cartel participants in itself suggests an impact on the market, even if the actual effect is difficult to measure, because it is, in particular, not known if and how many other projects were subject to bid-rigging, nor how many projects may have been subject to allocation between cartel members without there being a need for contacts between them. The high aggregate market shares of the cartel participants make anticompetitive effects appear likely and the relative stability of these market shares throughout the duration of the infringements would confirm these effects." $\underline{18}$ (emphasis added.)

Beyond the Commission's own concession of its inability to quantify the loss, the Brussels Court further added that even if the price increase was the sought intention of the market 
allocation scheme, it could not be directly derived from this that the cartelists had succeeded in their intentions (specifically for maintenance contracts concluded in Belgium with the European Institutions).

Possibly to overcome those difficulties, the Commission had ordered an expert report to MAPP, an economic consultancy, to quantify the loss. The MAPP report covered the analysis of a sample of 16 contracts: 11 during the existence of the cartel and 5 subsequent to the cartel. $\underline{19}$ The MAPP did not cover the period before the existence of the cartel (1996) and was confined to Belgium and Luxembourg.

In what probably constitutes the core of the judgment, the Brussels Court found that the Commission brought insufficient evidence of the "certainty" and of the "tangibility" of the damages suffered due to the cartel. The Commission failed to provide answers to questions relating to the overcharge of each of the maintenance contracts, or to determine which part of the overcharge was to be considered as stemming from the cartel and which part was due to other factors. Moreover, the evidence provided about a surplus paid during the period of the cartel as compared to the period subsequent to its existence was neither certain, nor tangible.

The Court also noted that the MAPP report took into consideration the data for both Belgium and Luxembourg even though the cartels in both countries were not organised in the same way. This was inconsistent with the Commission's decision, which had defined both markets as separate ones. $\underline{20}$ The Brussels Court had therefore no other choice but to conclude that both cartels could not have had the same average influence on the prices in both countries.

It is noteworthy that the Brussels Court expressed very strong words against the credibility of the expert economic report. This was in particular the case in relation to the contention that the cartel led to artificial price increases. The Commission had argued in its written pleadings the existence of an "artificial price increase" estimated at 15 per cent and damages of $€ 5$ million caused by the cartel both for the Belgian and Luxembourg markets. Meanwhile, the MAPP report that the Commission itself had ordered identified a surplus of 44 per cent but estimated exact similar damages of $€ 5$ million only for the Belgian market. The Court thereby considered that the economic expert report was overly farfetched and even questioned its credibility. It noted that the Commission's statement*E.C.L.R. 388

"that the exclusion of the Luxembourg contracts does not substantially modify the estimated surplus paid by the Claimant makes [the report] even less credible".

The Brussels Court could not therefore assume the existence of a causal link between, on the one hand, the infringement established in the Commission's decision and, on the other hand, the increased price allegedly due to the maintenance contracts. For the abovementioned reasons, the Brussels Court ruled that the Commission had not provided cogent evidence in 
support of its arguments. In particular, it observed that the Commission had not proven that each maintenance contract was to be separately examined to consider whether a surplus was created due to the market allocation. And it had not explained to what extent the cartel allowed its participants to keep certain margins on the maintenance contracts without necessarily raising the price.

The Brussels Court finally assessed the Commission's possible loss of opportunity. Again, the Elevators decision partly contradicted the damages claim. The Commission had explicitly acknowledged in its decision that it was impossible to determine with sufficient certainty the relevant competitive parameters (price, commercial terms, quality, innovation, and others) in the absence of the infringements. $\underline{21}$ The Brussels Court therefore argues that, at most, the alleged harm consisted of a loss of opportunity: to avoid the surplus paid and not the surplus in itself. The damages would then consist of the economic value of the loss of opportunity to avoid the surplus paid, rather than the so-called overcharge (surplus) paid.

The restrictive position of the Brussels Court on the loss of opportunity follows a judgment of the Belgian Cour de Cassation of April 1, $2004 \underline{22}$ pursuant to which, some prominent (Belgian Civil Law) authors have argued that the (trial) judge can no longer award damages through the loss of opportunity, in case of an uncertain causal link. This loss of opportunity can thus not cover for the uncertainty. The Brussels Court, aligned with this school of thought, ruled that the loss of opportunity could only be awarded when the causal link between the loss of opportunity and the harmful event is proven and leads to damages that are real, i.e. quantifiable. In view of the insufficient evidence provided by the Commission, the Brussels Court rejected its claims.

\section{Additional commentary}

The proceedings before the Brussels Court have been concomitant to the Commission's legislative attempts to promote the adoption of an "Antitrust Damages Directive". $\underline{23}$ On November 2014, just a few days before the Brussels Court rejected the Commission's complaint, the Damages Directive was formally approved. Unsurprisingly, the release of the judgment was welcomed with some irony. $\frac{24}{}$ But, leaving sarcasm behind, an important question that arises is whether the judgment would have changed had the Damages Directive been implemented at that time. $\underline{25}$

Let us recall a number of issues that the Directive tackles and that could have played an important role in the proceedings before the Brussels Court. First, the Damages Directive stipulates that victims of an infringement must have the right to claim full compensation covering compensation for actual loss, loss of profit and interest. In order to achieve this objective, the Directive establishes a rebuttable presumption that cartel infringements cause harm. 
Secondly, notwithstanding this objective and the detailed provisions of the Damages Directive, Member States retain discretion on several aspects, such as causation and the quantification of harm to secure the effectiveness and equivalence principles. $\underline{26}$

The Brussels judgment makes clear that the Court rejected the Commission's action for damages on lack of evidence and arguments brought by the claimant to prove damages (i). But it remains uncertain from the Brussels Court's wording whether it did not accept the presumption that public tenders cause damages in this specific cartelised market where not all players are involved (ii).

\section{(i) Lack of evidence or insufficient proof}

It is apparent that the Brussels Court based its assessment on the lack of evidence brought by the Commission. The Brussels Court blamed the Commission for its failure to adequately prove the damages caused by the surplus paid for the maintenance contracts obtained through public tenders in this specific cartelised market in which not all players were part of the cartel. $\frac{27}{}$ The Brussels Courts painfully recalled the Commission that 30 per cent of the market players were not involved in the cartel and could compete for the same public tenders. Moreover, the Commission admitted in its infringement decision, that despite public tenders being part of the cartel, their presumable surplus could hardly be assessed. It therefore remained up to the Commission to prove the concrete existence of its incurred damages.

\section{(ii) The presumption that bid-rigging cartels cause damages}

The Brussels Court simply refutes that contracts obtained through public tenders in this specific cartelized market in which not all players were involved can be affected by*E.C.L.R. 389 the cartel. This idea is likely to generate discussion. It can be considered both from a legal (a) and economic perspective (b)

\section{(a) Legal analysis}

\section{Article 16 of Regulation 1/2003 states that}

"(w)hen national courts rule on agreements, decisions or practices under Article 101 or Article 102 of the Treaty which are already the subject of a Commission decision, they cannot take decisions running counter to the decision adopted by the Commission".

This rule means that a plaintiff does not have to prove the infringement again, only that she has suffered damages from it. $\underline{28}$ As a consequence, the Brussels Court was right to follow the Commission's assessment in its infringement decision, wherein it decided that the cartel also included the market allocation for public tenders. However, art.16 does not diminish the judge's power of appraisal. In particular, he remains free to assess the damages resulting from the harmful event and the causality link between both. $\underline{29}$ 


\section{(b) The economic perspective}

The Brussels Court erred in considering that no surplus can derive from a bid-rigging cartel that does not involve all market players. Indeed, the Brussels Court appeared to be concerned with: (i) the bid-rigging nature of the cartel; and (ii) cartel incompleteness.

\section{(i) The bid-rigging nature of the cartel}

Economic theory, and a sense of logic too, demonstrate that cartel duration is an indicator of its success or profitability to its members. Essentially, the effectiveness of a cartel stems from its overcharge, i.e. the price increase that its members can obtain due to their collusive conduct. Driven by the objective of joint profit maximisation, firms collude, and collude for long periods of time. $\underline{30}$ The elevators cartel was in force for seven years and eight months until the Commission started its investigation. Had the cartelists not been able to benefit from the cartel due to the competitive pressure from cartel outsiders, they would have rationally put an end to it. $\underline{31}$ Since we do not have access to the specific data set of the cartels, we can only assume a number of advantageous variables for the cartelists, such as lower costs, economies of scale or output constraints as compared to the outsider(s). $\underline{32}$

The bid-rigging cartel at issue was mainly characterised, but not only, by a set of phantom bidding schemes. Under these schemes cartelists would submit artificial high bids to manifest presence of competition and designated a winner among them that would submit the lower bid in that auction. $\underline{33}$ By their very nature, phantom bidding schemes require more communication and explicit discussion of prices amongst the cartelists. However-quite counter-intuitively-antitrust authorities have more difficulties to detect collusion when there is more communication between cartel members, as it creates an appearance of competition. $\underline{34}$

Regarding the first concern, the Brussels Court refers to a relevant passage of the Oxera study, which the Commission had ordered and wherein it was stated that

"there is a small but significant proportion of cartels (7\%) where there is no overcharge. Whether a particular cartel falls into this category would need to be explored on a case-bycase basis".

By referring to this passage it appears that the Brussels Court wants to emphasise it is no task from any court to come up with prove for damages that a victim allegedly incurred. Still, it can be derived from the overall context of the judgment that the Brussels Court seems-to say the least-very reluctant to accept the existing recent economic theory showing that bidrigging cartels lead to overcharges. Furthermore, it is widely believed that bid rigging leads to higher overcharges than other types of collusive activities. Interestingly, in a recent empirical analysis of cartel overcharges Bolotova (2009) corroborates the wide believe that bid rigging 
leads to ["slightly"] higher overcharges than non-bid-rigging cartels. $\underline{35}$

Lastly, it is noteworthy that the US Sentencing Commission believes that the seriousness of bid-rigging cases is often understated. For this reason, the US Sentencing Commission has specified a 1-level increase for bid-rigging in the submission of non-competitive bids. $\frac{36}{B}$ Bidrigging cartels face higher fines as compared to other types of cartels. *E.C.L.R. 390

\section{(ii) Cartel incompleteness}

The second concern of the Brussels Court lies on the incompleteness of the cartel. In fact, KOST accounted for approximately 71 per cent by volume of maintenance services of elevators and escalators in Belgium. $\frac{37}{}$ The concern of the Brussels Court is not moot, as a cartel that does not involve all the potential bidders may lose the bidding even when it bids in excess of the reserve price. When the cartel is set up only to obtain one tender, the concern of the Brussels Court could be justified. Indeed, in a one-stage game where competitors outside the cartel cannot track an evolution of a set of cartelised prices, they could not eventually follow a non-existent cartelised market trend. Nevertheless, as the Commission showed in its decision, the duration of the cartel affected a large number of tender procedures.

In the markets under scrutiny, we can consider that in an auction market characterised by an oligopolistic number of participants-irrespective of their participation to a cartel-and with relatively homogeneous products or services, all participants to the tender would have been able to recognise the winning price to the tender. This understanding of the market is acceptable, considering that an auction market with a small number of players lends itself to transparency and therefore to knowledge of competitors' product prices.

Let us therefore assume that the outsider knows of the existence of the cartel and is capable of foreseeing price trends. Under similar costs functions, or no capacity constraints, the "outsider" would slightly undercut the price charged by the cartelists. Putting forth a simple numerical example, the outsider could offer the service for $€ 9.99$, to undercut the $€ 10$ offered by the selected cartelist winner. Leaving the analysis at this stage would mislead the reader in thinking that the Commission was not being overcharged for the service. Yet, had the cartel not been in force, fierce competition between the cartelists would have taken place and it would have lowered the final price the Commission paid: if the cartel had not been in force, the cartelists would have offered a lower price than $€ 9.99$, facing each other's competitive constraint. Most likely, the cartel created an "umbrella effect" allowing non-cartelists to overcharge their contracts. The cartelist priced the winning bid at $€ 10$ because it allowed them to benefit from an overcharge that would have not been possible in the absence of the cartel.

As explained above, $\underline{38}$ given the cartel duration, and rationally assuming a number of 
advantageous variables for the cartelists (otherwise the cartel would have not been sustainable in the long run), such as lower costs, economies of scale or output constraints as compared to the outsider, we can fairly assume that the Commission would have ended paying a lower price than the one it paid to the cartel outsider. $\underline{39}$

This strategy of repeatedly undercutting the bid by the outsider would, however, likely be swiftly discovered and might therefore finally lead to tacit collusion or oligopolistic interdependence in a highly concentrated market, such as the one at case. Nevertheless, this behaviour escapes antitrust liability under the Wood Pulp precedent. $\underline{40}$

Finally, assuming the contrary situation where the outsider is not aware of the cartel or its effects on price, the consequences of a one-stage game as assumed before, is transposable to an infinite repeated game, (i.e. an indefinite number of auctions) because the outsider does not represent a competitive constraint to the cartel.

\section{Conclusion}

With the proceedings before the Brussels Court, the Commission emphasised its growing need to promote claims for damages for infringements of EU competition law. Ahead of the implementation of the Damages Directive, and with its own infringement decision in hand, this claim seemed to be an easy exercise for the Commission to recoup the allegedly unlawful overcharge paid for the maintenance contracts.

Proof of incurred damages and causation were at the core of the proceedings. Although the Damages Directive will innovate in several important respects, such as the implementation of the rebuttable presumption of damages, causation and quantification of harm remain to the sole discretion of the national judges. Those principles, assessed under national law, have proven to be difficult to substantiate in the realm of incomplete bid-rigging cartels.

Consequently, a question that remains uncertain-for now-is about the strategy that the Commission will follow (if it does) on appeals. In our understanding, the Commission will need to individually quantify the surplus paid in each contract, and globally address the concerns that the appeals court may have with incomplete bid-rigging cartels.

\section{Jorge Marcos Ramos}

\section{Daniel Muheme}

E.C.L.R. 2015, 36(9), 384-390

*. PhD researcher in competition law, University of Liege (ULg), LCII, email: jorge.marcosramos@ulg.ac.be.

**. Research assistant at University of Liege (ULg), LCII and lawyer at the Brussels Bar, email: daniel.muheme@ulg.ac.be. The authors are grateful to S. Broos, N. Neyrinck, N. Petit, J. Teusch and A. Vanderelst for their insightful comments. Any interpretations and possible errors are ours, and shall not be attributed to the people who commented on this article. This research has benefited from the financial support 
of the "Actions de recherche concertées" (ARC), of the French Community of Belgium.

1. The Court of Justice of the European Union (CJEU) had already dispelled the doubts of the Brussels Court surrounding the Commission's ability to claim damages whilst it had been the judge in first instance of the case. It solved this Montesquian question by holding that the full effectiveness of EU law requires that any natural or legal person, including the European Union, can claim compensation for harm suffered as a result of a violation of competition rules.

2. See Case COMP/E1/38.823 - PO/Elevators and Escalators February 21, 2007, C(2007) 512 final (Elevators decision).

3. The four undertakings developed a system of code names to cover their real identities. KOST is their acronym.

4. On this point the Brussels Court considered that the Commission did not provide, under Belgian law, the necessary evidence to prove the fraud committed by KOST.

5. The Brussels Court judgment starts by reaffirming the interim judgment of April 18, 2011 where it had already established the existence of four cartels in four different markets. Importantly, the Brussels Court had already declared to have no jurisdiction over KOST that are established in Luxembourg.

6. See European Commission v Otis NV (C-199/11) EU:C:2012:684; [2013] 4 C.M.L.R. 4. The principle lex specialis generalibus derogat as put forward by KOST in relation to the adoption of budgetary measures was not applicable.

7. See Otis NV EU:C:2012:684 at [27]-[36].

8. See Manfredi v Lloyd Adriatico Assicurazioni SpA (C-295/04)_[2006] E.C.R. I-6619 at [59]-[61]. See also Courage Ltd v Crehan (C-453/99) [2001] E.C.R. I-6297.

9. Manfredi [2006] E.C.R. I-6619 at [63] and [64]: "(63) (...) Article 81 EC must be interpreted as meaning that any individual can rely on the invalidity of an agreement or practice prohibited under that article and, where there is a causal relationship between the latter and the harm suffered, claim compensation for that harm; (64) In the absence of Community rules governing the matter, it is for the domestic legal system of each Member State to prescribe the detailed rules governing the exercise of that right, including those on the application of the concept of 'causal relationship', provided that the principles of equivalence and effectiveness are observed."

10. See judgment of the (Dutch-speaking) Brussels Court of Commerce (fifth chamber) of November 24, $2014-$ Commission $v$ Producers of elevators, p.18.

11. Article 16 of Council Regulation (EC) 1/2003 of 16 December 2002 on the implementation of the rules on competition laid down in Articles 81 and 82 of the Treaty[2003] OJ L1/1 (Regulation 1/2003).

12. See, e.g. Cass., 14 mai 2003, R.G.A.R., 2003, n 13767.

13. See, e.g. Cass., 11 octobre 1989, R.G.A.R., 1992, nº 12.007.

14. J. Ronse, L. De Wilde, A. Claeys and I. Mallems, "Schade en schadeloosstelling", I in APR, Gent, StoryScientia, 1984, 173; E. Dirix, Het begrip schade (Antwerpen: Kluwer, 1984), p.16.

15. Article 17(2) of Directive 2014/104/EU of the European Parliament and of the Council of 26 November 2014 on certain rules governing actions for damages under national law for infringements of the competition law provisions of the Member States and of the European Union Text with EEA relevance [2014] O] L349/1 (Damages Directive).

16. Oxera, Quantifying Antitrust damages: towards non-binding guidance for courts. Study prepared for the European Commission, December 2009, http://ec.europa.eu/competition/antitrust/actionsdamages/quantification_study.pdf [Accessed July 8, 2015].

17. The Commission had claimed that all competing producers of elevators were involved in the cartel.

18. See Elevators decision at [660].

19. The number of maintenance contracts concluded in Belgium during the relevant period was unknown to the Commission.

20. See Elevators decision at [689] and operative part.

21. See Elevators decision at [588] and [660].

22. See Cour de Cassation, April 1, 2004; I. Boone, "Het verlies van een kans bij onzeker causaal verband", R.W, 2004-2005, 96.

23. Already, in 2005 the Commission issued a Green Paper and in 2008 a White Paper on Damages actions for breach of the EC antitrust rules.

24. See A. Lamadrid, No comment, November 25, 2014, http://chillingcompetition.com/2014/11/25/nocomment-2/_ [Accessed July 8, 2015].

25. See http://ec.europa.eu/competition/antitrust/actionsdamages/directive_en.html [Accessed July 8, 2015]: Member states have two years (until December 26, 2016) to implement the Directive into their domestic law.

26. See VWEW Advocaten newsletter, The European Antitrust Damages Directive, January 22, 2014, http://www.vwew.be/newsitems/view/27 [Accessed July 8, 2015].

27. This is to the best of our knowledge, as the MAPP report is not publicly available. 
28. D. Chalmers, G. Davies and G. Monti, European Union Law (Cambridge: Cambridge University Press, 2010), p.956.

29. See Manfredi [2006] E.C.R. I-6619.

30. G.J. Stigler, "A theory of oligopoly" (1964) 72 The Journal of Political Economy 44.

31. See Elevators decision, p.105, [645] and [692], "In this case, the Commission's investigation started with the surprise inspections pursuant to Article 14()ㅡㅇ of Regulation No 17 on January 282004 for Belgium ...".

32. Elevators decision at [165] might point in this direction. "In June 2002, [**] specifically asked the other undertakings to include new elevator projects for the cartel only if the value was above EUR 300,000" Although the other cartel members accepted this suggestion, it is reported that "hat projects of a lower value were continuously put on the project lists after September 2002".

33. See K. Hendricks, R.P. McAffee and M.A. Williams, "Auctions and Bid Rigging" in R.D. Blair and D. Sokol (eds), The Oxford Handbook of International Antitrust Economics Vol.2 (Oxford: Oxford University Press, 2014).

34. Contrary to phantom bids, in pure bid rotation schemes the cartel designates a winner for each project who will be the only cartelist submitting a bid. In this situation, the "sudden" disappearance of market competitors would swiftly draw the attention of the enforcement authorities. In this sense, and the distinction between phantom and pure bid rotation cartels see S. Gupta, "The Effect of Bid Rigging on Prices: A Study of the Highway Construction Industry" (2001) Review of Industrial Organization 453.

35. Y.V. Bolotova, "Cartel overcharges: An empirical analysis" (2009) 70 Journal of Economic Behavior \& Organization 321. The empirical analysis uses 406 estimates building on the data set developed by J.M. Connor, "Price-fixing overcharges: legal and economic evidence" (2005) Staff Paper No.04-17, Department of Agricultural Economics, Purdue University, West Lafayette, IN.

36. United States Sentencing Commission, Guidelines Manual, para.3E1.1 (November 2014) Part R-Antitrust Offenses, p.309 and para.2R1.1.

37. See Elevators decision at [44] and [50]-[60] referring to market shares of the cartelists as of 2003. This is the only non-redacted figure relating to the Belgian market.

38. See above, text accompanying fnn.31-33.

39. In Elevators decision at [662], the Commission considered that the cartelists were unlikely to face competitive constraints exercised by smaller elevator and escalator companies, and thus prevent them from fixing supracompetitive prices.

40. See A. Ahlström Osakeyhtiö v Commission of the European Communities (Joined Cases 89, 104, 114, 116, 117 \& 125-129/85) [1994] E.C.R. I-99.

(c) 2017 Sweet \& Maxwell and its Contributors

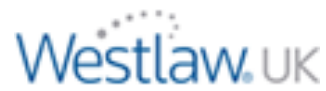

